\title{
Immunohistochemical Study of Intestinal Lamina Propria Cells in the Rat, with Special Reference to Ia Antigen Expression
}

\author{
By \\ Bunsuke OSOGOE ${ }^{1)}$ and Tetsuo FUKUMOTO ${ }^{2)}$ \\ 1)Division of Pathology, Shigei Medical Research Institute, \\ 2117 Yamada, Okayama 701-02, Japan \\ ${ }^{2)}$ Department of Anatomy*, Yamaguchi University School of Medicine, \\ Ube, Yamaguchi 755, Japan.
}

- Received for Publication, November 15, 1989-

Key words: Lamina propria cells, Reticulum cells, Rat intestine, Ia antigen, IgA

\begin{abstract}
Summary: A previous study by Osogoe and Yanagi (1987a) has demonstrated that a large proportion of the lamina propria cells (LPC), mostly reticulum cells, in the core of the rat jejunal villi exhibit a strong labeling with $\left[{ }^{14} \mathrm{Cladenine}\left(\left[{ }^{14} \mathrm{C}\right] \mathrm{A}\right)\right.$. To obtain further information on such LPC, immunohistochemical detection of either la antigen or IgA on intestinal LPC was carried out in adult rats.

It was found that almost all the LPC in the villous core of the small intestine express Ia antigen, and that in this area IgA-containing $B$ cells also occur in unexpectedly large numbers. However, the number of Ia-positive non-B cells was greater than that of IgA-containing B cells which are also Ia-positive. Since the Ia-positive non-B cell population is composed mostly of reticulum cells, the above findings indicate that a large number of LPC, mostly reticulum cells, not only exhibit a strong labeling with $\left[{ }^{14} \mathrm{ClA}\right.$ but also express Ia antigen. The biological significance of la antigen expression is discussed in relation to the proliferative activity of the cells.
\end{abstract}

An earlier study on adult rats by Osogoe and Yanagi (1987a) has demonstrated that a large proportion of the lamina propria cells (LPC), mostly reticulum cells, in the core of the rat jejunal villi exhibit a strong labeling with $\left[{ }^{14} \mathrm{C}\right]$ adenine $\left(\left[{ }^{14} \mathrm{C}\right] \mathrm{A}\right)$. Concerning the LPC of the small intestinal villi, two important items of information have been reported in the literature. One is that the LPC in question express Ia antigen (i.e., one of the surface markers of the cells that participate in the immune responses) (Mayrhofer et al., 1983). The other is that the villous LPC of the small intestine include numerous IgA-producing B cells (Parrott, 1976; Bienenstock et al., 1980; McCaughan and Basten, 1983; Yachi, 1989). Since the B cells are known to be Iapositive, it is necessary to detect IgA (along with Ia antigen) for the identification of B cells and non-B cells among the villous LPC of the small intestine.

In the present study, therefore, immunohistochemical detection of either Ia antigen or $\operatorname{Ig} \mathrm{A}$ on the intestinal LPC was carried out in adult rats. The aim was to obtain further information concerning the LPC which are capable of incorporating $\left[{ }^{14} \mathrm{C}\right] \mathrm{A}$ to a great extent, as reported previously by Osogoe and Yanagi (loc. cit.).

\section{Materials and Methods}

Animals. A total of 14 male adult rats of the Wistar strain weighing around $200 \mathrm{~g}$ were used. They were divided into two groups: 8 for detecting Ia antigen and 6 for detecting $\operatorname{IgA}$ on the tissue cells to be examined.

Indirect immunohistochemical staining for either Ia antigen or $\operatorname{Ig} A$. Indirect immunohistochemical staining of LPC of the small intestine, colon, stomach and esophagus was performed according to the methods described by Fujikura et al. (1985).

1. Staining for Ia antigen. As the primary antibody, mouse monoclonal anti-rat Ia: OX-6 (Serotec, Ltd., Bicester, Oxfordshire, U.K.) was used. Each $10 \mu \mathrm{m}$ frozen section of tissue was incubated with $100 \mu \mathrm{l}$ of the primary antibody for $1 \mathrm{hr}$ at room temperature, washed three times with ice-cold phosphate-buffered saline (PBS) and then incubated at $4^{\circ} \mathrm{C}$ for $1 \mathrm{hr}$ with $100 \mu \mathrm{l}$ of horseradish peroxidase conjugated rabbit $\mathrm{F}\left(\mathrm{ab}^{\prime}\right)_{2}$ anti-mouse IgG (Cappel Laboratories, Inc., West Chester, PA, U.S.A.). After washing with PBS, the peroxidase was revealed using diaminobenzidine and the section was lightly counterstained with hematoxylin.

2. Staining for $\lg A$. As the primary antigen, mouse monoclonal anti-rat IgA (Zymed Laboratories, Inc., 
San Francisco, U.S.A.) was used. The other procedures were the same as those above (1).

3. Control. Each series of staining procedures (1 or 2 ) in which the reaction with the primary antibody was omitted, served as the control. In the control, the activity of endogenous peroxidase alone was expressed.

\section{Results}

Villous lamina propria of the small intestine. In the lamina propria of small intestinal villi, particularly that of duodenal villi, almost all the LPC, as well as the villous epithelium, were found to express Ia antigen (Fig. 1a, Plate I). In the control staining without the primary antibody reaction, neither the LPC nor the epithelia were stained at all, with the exception of a few dark-staining cells which expressed the activity of endogenous peroxidase (i.e., macrophages) (Fig. 1b, Plate I). In some instances, small aggregations of Ianegative $T$ cells were observed in the lamina propria, being intermingled with Ia-positive cells.

Further immunohistochemical staining for $\operatorname{IgA}$ on the villous LPC of the small intestine revealed, however, that a large number (about $1 / 3$ ) of these cells contained IgA (Fig. 2a, Plate II). In the control staining without the primary antibody reaction, no staining was noted on the villous LPC, except in a few cells which revealed a positive reaction for endogenous peroxidase (i.e., macrophages) (Fig. 2b, Plate II).

Mucosal lamina propria of the colon, stomach and esophagus. In the colonic mucosa which lacks villi, Ia- positive cells were also observed in the lamina propria between neighboring crypts, but in far lesser numbers than those present in the villous lamina propria of the small intestine (Fig. 3, Plate III). Ia-positive cells were found to be very few (or nearly absent) in the mucosal lamina propria of the stomach and esophagus (Figs. 4 and 5, Plate III),

Morphological features of Ia-positive or IgAcontaining cells. The majority of the Ia-positive cells were large in size and had a large, ovoid or round, euchromatic nucleus surrounded by abundant cytoplasm which stained positively for Ia antigen (Figs. 1a and 1b, Plate I). Mayrhofer et al. (1983) reported that the cytoplasm of Ia-positive cells in the villus lamina propria had numerous long cytoplasmic processes. However, such cytoplasmic processes of the Ia-positive cells were not seen in the present study. The morphological features of the IgA-containing cells were similar to those of the Ia-positive cells; they were characterized by a large cell body having a large euchromatic nucleus and abundant cytoplasm which stained positively for IgA (Figs. 2a and 2b, Plate II). Contrary to the authors' expectations, the nucleus of the IgA-containing cells was not so pachychromatic and did not bear the typical, clock-face appearance which is characteristic of the nucleus of the mature plasma cell (cf. Fig. 2a with Fig. $2 b)$.

The present findings for Ia-positive and IgAcontaining cells in the intestinal lamina propria, together with the previous observations on the $\left[{ }^{14} \mathrm{C}\right] \mathrm{A}$ labeling of intestinal LPC (Osogoe and Yanagi, 1987a, b), are summarized in Table 1.

Table 1. Summary of results of immunohistochemical and autoradiographic examinations of cellular elements in the villous lamina propria of the small intestine

\begin{tabular}{lllll}
\hline Cell type & Number of cells & Ia antigen & IgA & {$\left[{ }^{14} \mathrm{C}\right] \mathrm{A}$ labeling ${ }^{2)}$} \\
\hline B cells & $\begin{array}{l}\text { about } 1 / 3 \text { of the } \\
\text { total number }\end{array}$ & + & + & - \\
T cells & small number & - & & - \\
Reticulum cells & $\begin{array}{l}\text { greater number } \\
\text { than B cells }\end{array}$ & + & & + \\
Fibroblasts & few & & & + \\
Macrophages & few & - & - & + \\
\hline
\end{tabular}

1)Leukocytes such as neutrophils, eosinophils and basophils were not observed.

2) Reported in earlier papers by Osogoe and Yanagi (1987a, b) and Osogoc and Umebayashi-Yanagi (1989).

${ }^{3)}$ The majority of IgA-containing B cells did not show the morphological features of typical mature plasma cells which have a pachychromatic nucleus giving a clock-face appearance. 


\section{Discussion}

The present results demonstrate that almost all LPC, as well as epithelial cells, of the small intestinal villi express Ia antigen. This finding coincides with those of Mayrhofer et al. (1983), who reported that the majority of LPC in the rat jejunal villi, along with the villous epithelium, are Ia-positive. However, these authors did not take into account the possibility that the observed Ia-positive LPC might include a larger number of B cells which express Ia antigen. The present study, on the other hand, has clearly substantiated the occurrence of an unexpectedly large number of $\operatorname{IgA}$-containing $\mathrm{B}$ cells (about $1 / 3$ of the total population of LPC) in the small intestinal villi. Here, the word "unexpectedly" is used because typical plasma cells, which have a pachychromatic nucleus giving a clock-face appearance, were rarely seen in the lamina propria of the small intestinal villi in normal adult rats (see Figs. $1 \mathrm{~b}$ and $2 \mathrm{~b}$ ).

Despite the occurrence of a large population of $\operatorname{IgA}$ containing $\mathrm{B}$ cells in the lamina propria of the small intestinal villi, the population of non-B cells that express Ia antigen (about $2 / 3$ of the total population of LPC) was still greater in size than the B cell population. The non-B cell population in this tissue is composed mostly of stromal cells, such as reticulum cells, fibroblasts and macrophages, although it also includes a small number of IgA-negative $\mathrm{T}$ cells (Table 1).

Concerning the stromal cells of the intestinal lamina propria, the prevailing view expressed in the earlier literature was that they were fibroblasts (or fibrocytes) similar to those present in the connective tissues of most other organs. However, the principal stromal cells in the villous lamina propria are now considered, from the histological standpoint, to be reticulum cells which form a network with fine argyrophil fibers (Fujita, $\mathrm{H}$. and Fujita, T., 1984). Such a view is supported by the previous findings of Osogoe and Yanagi (1987a, b) which showed that a proportion of the stromal cells of the villous lamina propria of the small intestine are capable of incorporating $\left[{ }^{14} \mathrm{C}\right] \mathrm{A}$ to a remarkable extent, quite similarly to the reticulum cells in the lymphoid tissues. According to Marsh and Trier (1974), true fibroblasts are not present in the core of the small intestinal villi of adult mice, with the exception of the subepithelial regions where a few fibroblasts occur. It seems evident therefore that the principal stromal cells of the villous lamina propria are reticulum cells.

In the mucosal lamina propria of the colon, Iapositive cells were also observed but in far lesser numbers than in the villous lamina propria of the small intestine. Such cells were found to be very few (or nearly absent) in the lamina propria of the stomach and esophagus.

The authors would now like to correlate the present results with the previous findings of Osogoe and Yanagi (1987a) that a large proportion of the LPC, mostly reticulum cells, in the villous lamina propria of the small intestine are heavily labeled with $\left[{ }^{14} \mathrm{C}\right] \mathrm{A}$. The present data have disclosed, on the other hand, that like B cells, non- $B$ cells in the tissue are also Ia-positive, and that the non-B cell population is composed mostly of reticulum cells. Combining the previous and present findings together, it can be said that a large proportion of the non-B cells, mostly reticulum cells, in the villous lamina propria not only exhibit a strong labeling with $\left[{ }^{14} \mathrm{C}\right]$ but also express Ia antigen.

The Ia antigen is one of the surface markers of the cells that participate in the immune reactions, such as B cells, some macrophages, Langerhans cells and dendritic cells, and its expression is correlated with a role in antigen recognition (Steinman et al., 1979; Tokunaga et al., 1981; Tew et al., 1982; Mayrhofer et al., 1983; Tizard, 1988). However, in the Ia-positive epithelial cells, such a role is not obvious. It is of particular interest to mention here that another aspect of Ia antigen expression has been suggested by Tizard (1988); this author states in his textbook of immunology (p.167) that less than $1 \%$ of normal $T$ cells are Iapositive, but after exposure to a mitogen (such as PHA), up to $70 \%$ become Ia-positive. In this case, Ia antigen expressed can be regarded as a sign of an increased activity of cell proliferation. In view of this, it is quite reasonable that intestinal LPC showing heavy labeling with $\left[{ }^{14} \mathrm{C}\right] \mathrm{A}$ should be Ia-positive, since uptake of $\left[{ }^{14} \mathrm{C}\right] \mathrm{A}$ is thought to occur in parallel with an increased activity of cell proliferation.

\section{Acknowledgements}

The authors wish to thank Mr. M. Tamechika and Mr. A. Kumakura, Department of Anatomy, Yamaguchi University School of Medicine, for their helpful technical assistance. They are also indebted to Miss N. Nishimoto, Shigei Medical Research Institute, for her secretarial assistance.

\section{References}

1) Bienenstock, J., Befus, A.D. and McDermott, M.: Mucosal immunity. Monogr. Allergy, 16: 1-18, 1980.

2) Fujikura, Y., Kuniki, H. and Fukumoto, T.: Monoclonal antibodies against fetal rat liver cells. Bull. Yamaguchi Med. Sch., 32: 21-26, 1985

3) Fujita, H. and Fujita, T: : A Textbook of Histology, Part 2, 2nd ed., Igaku-Shoin, Tokyo, 1984, p. 126 (in Japanese).

4) Marsh, M.N. and Trier, J.S.: Morphology and cell proliferation of subepithelial fibroblasts in adult mouse jejunum. II Radioautographic studies. Gastroenterology, 67: 636-645, 1974.

5) Mayrhofer, G., Pugh, C.W. and Barclay, A.N.: The distribution, ontogeny and origin in the rat of Ia-positive cells with dendritic morphology and of la antigen in epithelia, with special reference to the intestine. Eur. J. Immunol, 13:117-122,1983. 
6) McCaughan, C. and Basten, A.: Immune system of the gastrointestinal tract. Int. Rev. Physiol., 28: 131-157, 1983.

7) Osogoe, B. and Yanagi, M.: Adenine uptake by lamina propria cells in the intestinal mucosa of rat and mice, with special reference to reticulum cells. Acta Histochem. Cytochem., 20: 387-397, 1987a.

8) Osogoe, B. and Yanagi, M.: Adenine uptake by reticulum cells in the lymphoid tissues of rats. Acta Histochem. Cytochem., 20: 399-408, $1987 \mathrm{~b}$.

9) Osogoe, B. and Umebayashi-Yanagi, M.: Adenine uptake by rat connective tissue cells with special reference to macrophage precursors. Okajimas Folia Anat. Jpn., 66: 169-180, 1989.

10) Parrott, D.M.V.: The gut as a lymphoid organ. Clinics in Gastroenterology, 5: 211-288, 1976.

11) Steinman, R.M., Kaplan, G., Witmer, M. and Cohn, Z.A.: Identification of a novel cell-type in peripheral lymphoid organs of mice. V. Purification of spleen dendritic cells, maintenance in vitro, and new surface marker of dendritic cells. J. Exp. Med., 149: 1-16, 1979.

12) Tew, J.G., Thorbeck, G.J. and Steinman, R.M.: Dendritic cells in the immune response: Characteristics and recommended nomenclature (a report from the Reticuloendothelial Society Committee on Nomenclature). J. Retic. Soc., 31: 371-380, 1982.

13) Tizard, I.R.: Immunology: An introduction. Saunders College Publishing, Philadelphia, New York, Chicago, etc., 1988, p.167, 205-206.

14) Tokunaga, T., Akagawa, K. and Tanaka, H.: On the role of Ia-positive A cells in immune responses. Metabolism and Diseases 18: 1463-1476, 1981 (in Japanese).

15) Yachi, A.: Immune mechanism of the gastrointestinal tract. Clin. Gastroenterol., 4: 1433-1444, 1989 (in Japanese). 
Plate I
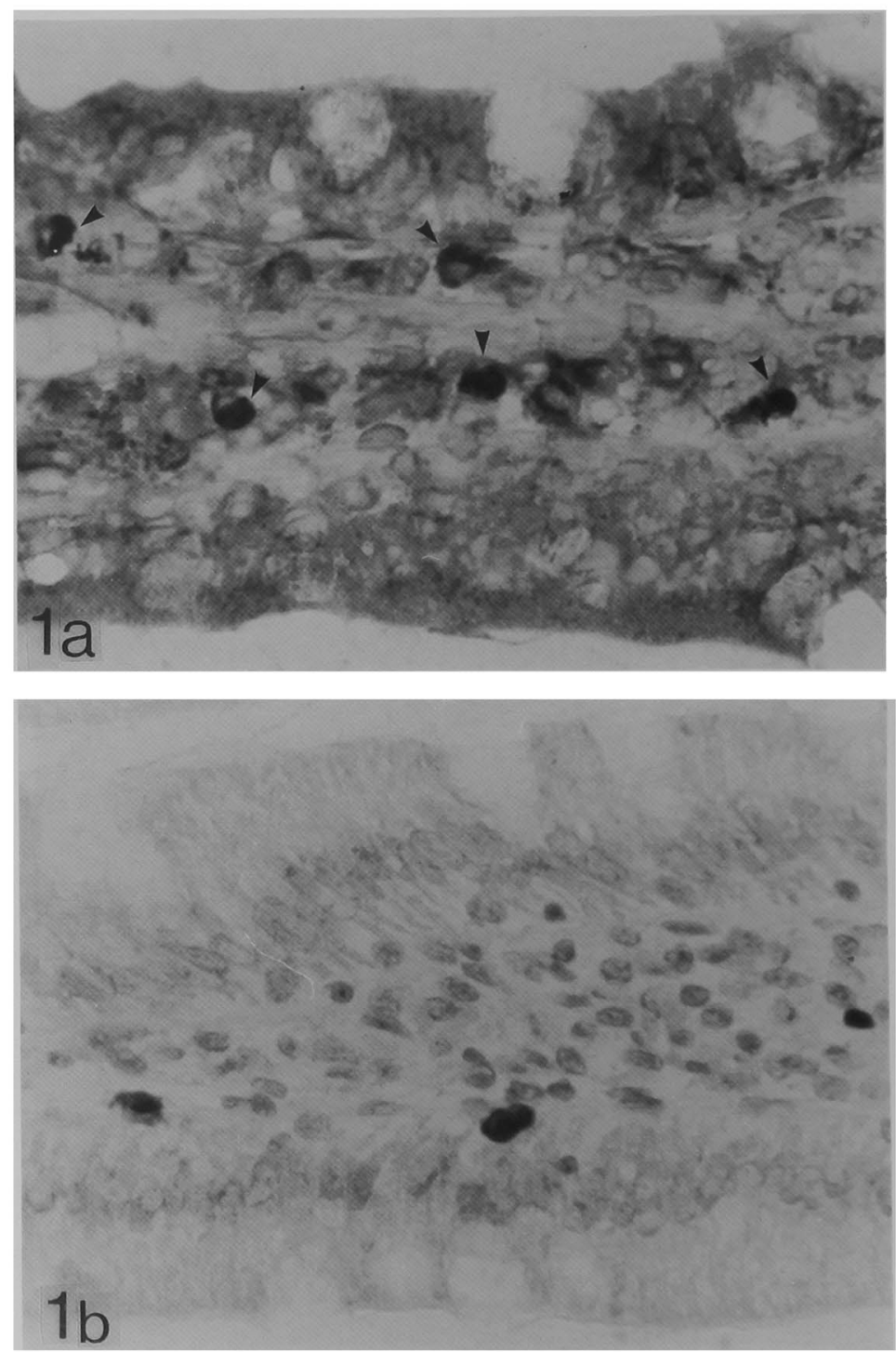

\section{Explanation of Figures}

\section{Plate I}

Fig. 1. Immunohistochemical staining for Ia antigen on cellular elements of the jejunal villus. Lightly counterstained with hematoxylin. $\times 450$.

(a) An example of la staining, illustrating a positive reaction on almost all cells in the lamina propria of the villous core, as well as on the villous epithelium. Note that several cells with particularly dark staining (arrowheads) represent macrophages.

(b) Control staining without the primary antibody reaction, showing a negative reaction on all cellular elements of the villus, with the exception of three dark-staining cells expressing the endogenous peroxidase (i.e., macrophages) in the lamina propria. 
Plate II
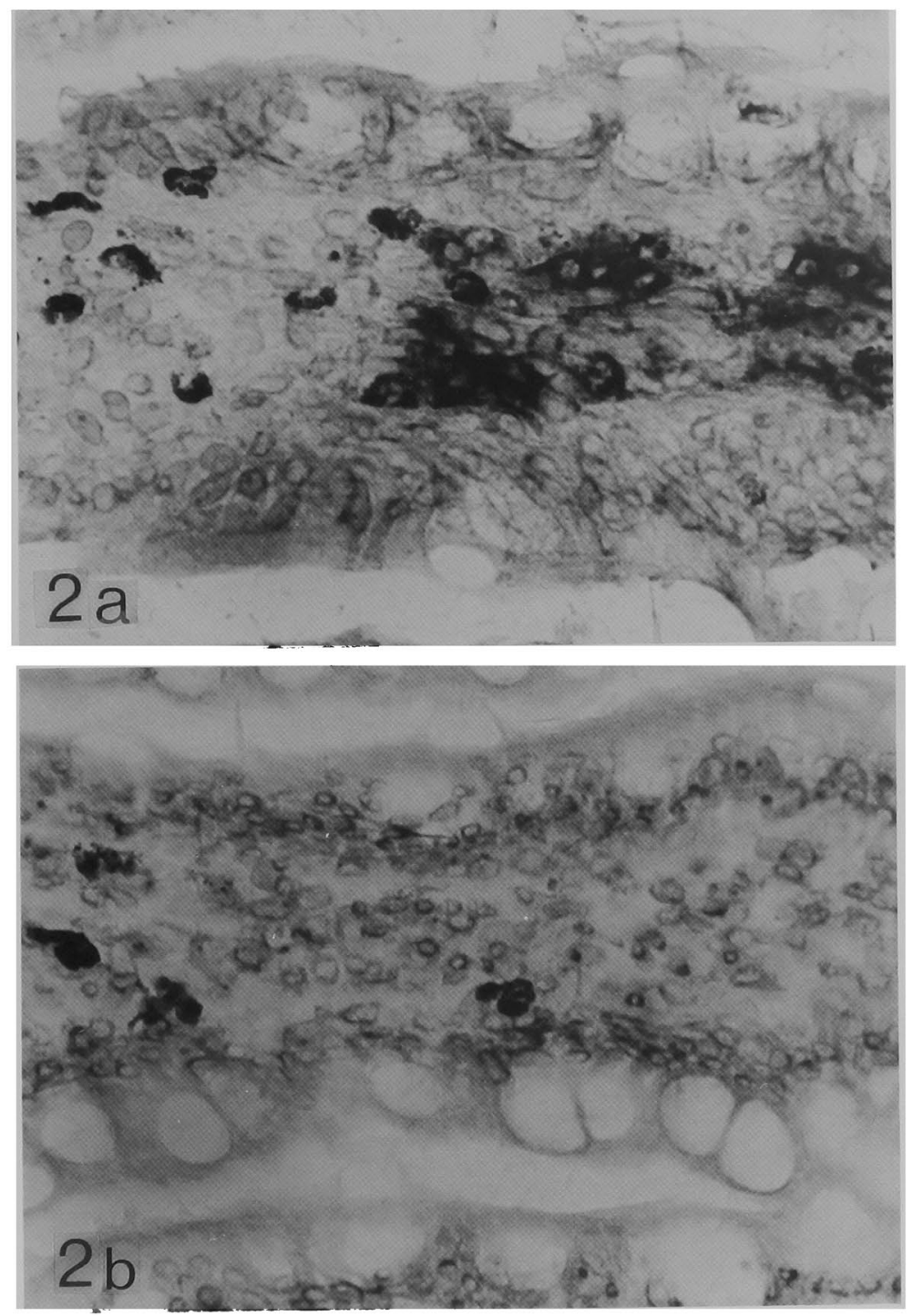

\section{Plate II}

Fig. 2. Immunohistochemical staining for IgA on cellular elements of the jejunal villus. Lightly counterstained with hematoxylin. $\times 450$.

(a) An example of Ia staining, illustrating a positive reaction on a large number of cells in the villous lamina propria. The villous (a) An example of la staining, illustrating a positive reaction on a large number of cells in the veroxidase (i.e., macrophages) in the left half of the lamina propria, where the other cells are unstained.

(b) Control staining without the primary antibody reaction, showing a negative reaction on all cellular elements of the villus, except for several dark-staining cells (macrophages). Note that typical mature plasma cells with a pachychromatic nucleus giving a clockface appearance are not observed in the lamina propria. 

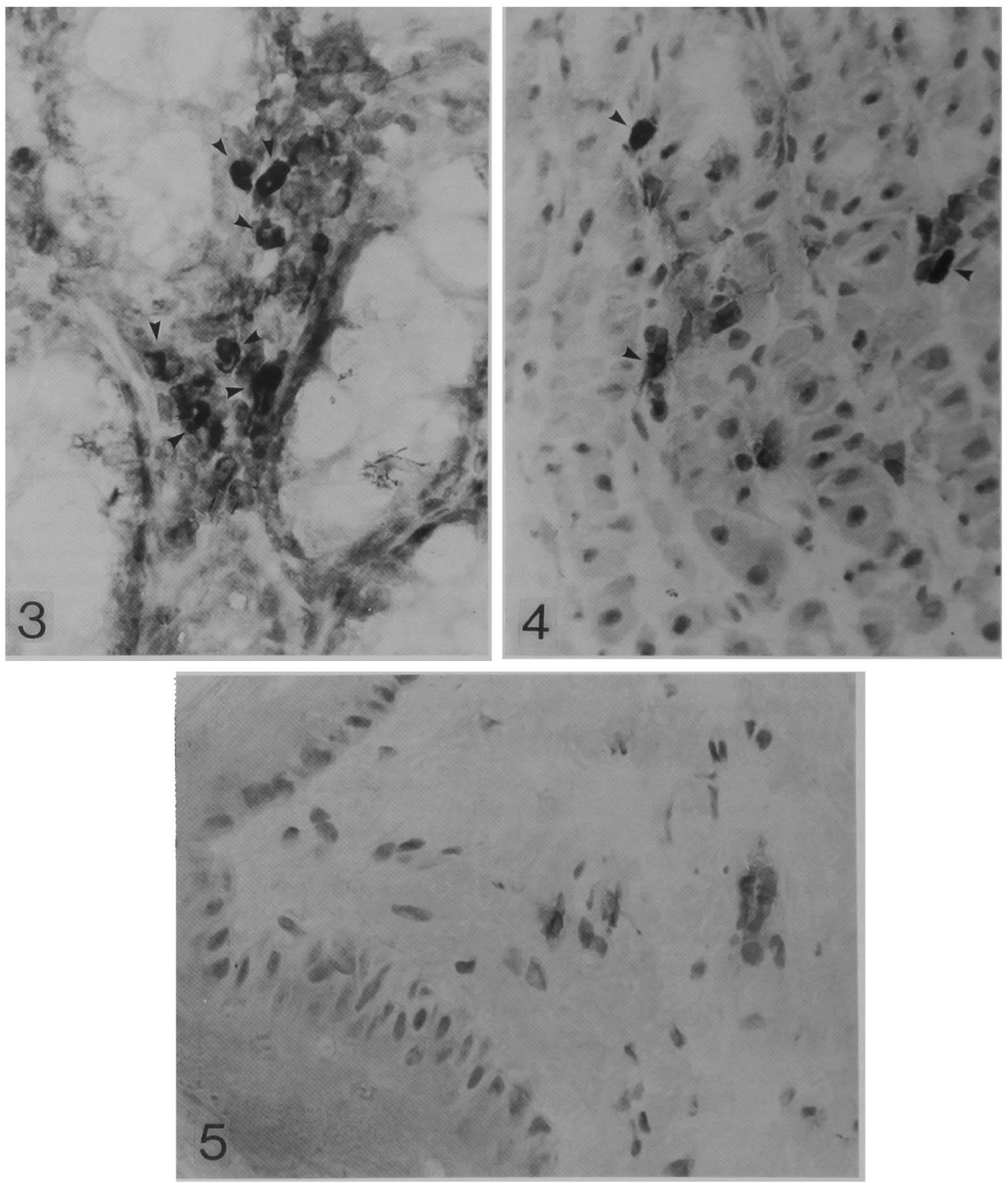

Plate III

Fig. 3-5. Immunohistochemical staining for Ia antigen on mucosal cells of the colon, stomach and esophagus. Lightly counterstained with hematoxylin. $\times 400$.

3. Ia staining of mucosal cells of the colon, illustrating a positive reaction on a limited proportion of the cells in the lamina propria between neighboring crypts. Note that several cells with particularly dark staining (arrowheads) represent macrophages. The epithelial cells of the crypts are almost unstained.

4. Ia staining of mucosal cells of the stomach. In the mucosal lamina propria, several cells appear to show a positive reaction. Note the three dark-staining macrophages (arrowheads). The epithelial cells of the gastric glands reveal a slightly positive reaction. 5. Ia staining of mucosal cells of the esophagus. In the subepithelial lamina propria, two or three cells appears to show a positive reaction. Macrophages are not present. Note that the superficial layer of the epithelium reveals a weakly positive reaction. 